Article

\title{
Experimental Evaluation of a New Giant Reed (Arundo Donax L.) Composite Using Citric Acid as a Natural Binder
}

\author{
Maria Teresa Ferrandez-Garcia, Clara Eugenia Ferrandez-Garcia, Teresa Garcia-Ortuño, \\ Antonio Ferrandez-Garcia and Manuel Ferrandez-Villena *(D)
}

Department of Engineering, Universidad Miguel Hernandez, 03300 Orihuela, Spain; mt.ferrandez@umh.es (M.T.F.-G.); cferrandez@umh.es (C.E.F.-G.); tgarcia@umh.es (T.G.-O.); antonio.ferrandezg@umh.es (A.F.-G.)

* Correspondence: m.ferrandez@umh.es; Tel.: +34-966-749-716

Received: 22 October 2019; Accepted: 10 December 2019; Published: 12 December 2019 updates

\begin{abstract}
The raw materials used to manufacture thermal insulation in buildings consume a large amount of energy and are not generally biodegradable, which means it is necessary to increase the use of renewable, eco-friendly resources such as plant fibers in order to reduce the environmental problems this generates. The wood adhesives developed by the petrochemical industry offer excellent performance and are affordable. However, their use has an expiry date and in the future they will be rejected due to the environmental and health problems they can cause. The objective of this work was to develop a new eco-friendly biocomposite that could be used for thermal insulation in buildings. Boards were manufactured from giant reed particles with a particle size of 2 to $4 \mathrm{~mm}$, using 5 and $10 \%$ by weight of citric acid as a natural binder. Experiments were then carried out to investigate the effect of board density on mechanical, physical, and thermal properties. A new type of composite was obtained with a thermal conductivity of $0.081-0.093 \mathrm{~W} / \mathrm{m} \mathrm{K}$, which makes it suitable as an insulating material. The boards with a density of $850 \mathrm{~kg} / \mathrm{m}^{3}$ had a modulus of rupture (MOR) of $12.5 \mathrm{~N} / \mathrm{mm}^{2}$, a modulus of elasticity (MOE) of $2440 \mathrm{~N} / \mathrm{mm}^{2}$, and an internal bonding strength (IB) of $0.61 \mathrm{~N} / \mathrm{mm}^{2}$, and they could be used as insulation panels for divisions and enclosures in buildings.
\end{abstract}

Keywords: thermal insulation; particleboards; mechanical; physical and thermal properties

\section{Introduction}

Buildings are responsible for $30 \%$ of the world's energy consumption and for $28 \%$ of $\mathrm{CO}_{2}$ emissions. A passive way of saving energy is by taking action to improve the thermal enclosure of buildings. In recent times, there are technical materials on the market that offer good insulating properties, including those of plastic origin (expanded polystyrene, extruded polystyrene, polyurethane foam, etc.) and those of mineral origin (glass fiber, rock wool, vermiculite, perlite, etc.), but their production consumes a large amount of energy and they are not biodegradable.

Due to the environmental problems deriving from their manufacture, the use of renewable and eco-friendly resources is growing, and this has led to a considerable increase in research works focusing on the use of plant fibers for developing new thermal insulation products and the use of natural adhesives.

A large amount of plant waste is currently burned, shredded, buried, or taken to landfill sites. Therefore, the use of these plant fibers as a natural and renewable element in insulating materials would have significant environmental and economic benefits, because the product would fix $\mathrm{CO}_{2}$ throughout the building's lifetime and would also be completely biodegradable at the end of its useful 
life. When choosing a natural insulating material, several factors should be considered, such as its thermal performance, availability, cost, installation method and ecological impact.

Studies have been carried out on the insulating properties of plant waste and fibers: coconut fiber [1], paper manufacturing waste and corn peel [2], kenaf fibers [3], cotton stalk fibers [4,5], coconut husk and bagasse [6], hemp fibers [7,8], date palm fibers and gypsum [9], flax [10], flax and hemp [11], rice straw [12], sisal [13], sugarcane bagasse [14], giant reed [15,16], Canary Islands palms [17], and Washingtonia palms [18].

Giant reed (Arundo donax L.) was used as a building material in many Mediterranean countries. In the south of the province of Alicante it was used in all buildings up to the beginning of the 20th century, mainly forming part of the roof and floor. It continued to be used in small detached houses and farm buildings until the 1960s. More recently, it is no longer used, thus leading to excessive growth of this plant population along river banks. This poses a serious threat when the water level rises, as the reeds can be easily ripped up by the force of the waters and result in problems such as blockage of bridges and other infrastructures. Therefore, the use of giant reeds for industrial purposes would provide an environmental advantage.

At present, most wood adhesives such as formaldehyde-based resins, vinyl acetate resins, and isocyanate-based resins are composed of different materials derived from fossil resources. Wood adhesives have been developed by the petrochemical industry and offer excellent performance, good working properties and are affordable. However, it is believed that the use of the current wood adhesives will inevitably be restricted in the future due to a decline in the reserves of fossil resources. This has led to a search for different types of natural adhesives for the formation of various insulation panels: lignin [19], starch [15] and tannins [20]. Citric acid has recently been studied as a natural adhesive for wood [14,21], bamboo [22], and sorghum stalk [23]. Citric acid is an organic polycarboxylic acid that contains three carboxyl groups. It is contained in citrus fruit like lemons and limes and is produced commercially by glucose or glucose and sucrose fermentation. It is stated in the aforementioned works [14,21-23] that the carboxyl groups of the citric acid reacted with the hydroxyl groups of the plant fibers to form ester bonds. This process favours binding between the particles and directly improves the properties of the boards that they form.

In this work, the use of a weed like giant reed for manufacturing particleboards with thermal insulation properties is discussed, using citric acid as a natural binder and consuming less energy in the manufacturing process than conventional industrial particleboards. These panels are completely eco-friendly and will provide considerable environmental benefits.

\section{Materials and Methods}

\subsection{Materials}

The materials used in this study were giant reed particles, citric acid monohydrate, and water.

The giant reed biomass was obtained from clearing the banks of the River Segura, in South-East Spain. The reeds were laid out to dry outdoors for 12 months. They were then cut and shredded in a blade mill. The particles were collected in a vibrating sieve and only those which passed through the $4 \mathrm{~mm}$ sieve and were retained in the $2 \mathrm{~mm}$ sieve were selected. The relative humidity of the particles was $9 \%$.

The citric acid monohydrate used had a minimum purity of $99.5 \%$ and was supplied by the company Diasa Industrial S.A., 30100 Murcia, Spain.

The water was taken directly from the municipal mains drinking water supply.

\subsection{Methods}

\subsubsection{Manufacture of the Particleboards}

The manufacturing process consisted of dry mixing of giant reed particles with different proportions of citric acid in relation to the weight of the reed particles ( $5 \%$ and $10 \%$ by weight). Then $10 \%$ by 
weight of water (based on the weight of the giant reed particles) was sprayed onto the mixture and it was stirred manually for $15 \mathrm{~min}$ to homogenise it. The mat was formed in a mould of dimensions $600 \mathrm{~mm} \times 400 \mathrm{~mm}$ and was subjected to pressure and heat in a hotplate press. The temperature used was $150{ }^{\circ} \mathrm{C}$ and they were pressed for $7 \mathrm{~min}$. The pressure of the press was changed, varying from 1.7 to $2.5 \mathrm{MPa}$ to obtain rigid agglomerated particle panels of different densities $(600,650,700,750,800$, $850 \mathrm{~kg} / \mathrm{m}^{3}$ ). The panels were then left to cool in a vertical position. The approximate dimensions of the particleboards were $600 \times 400 \times 10 \mathrm{~mm}$ and they were placed in a normal climate chamber at a temperature of $20^{\circ} \mathrm{C}$ and relative humidity of $65 \%$ for one week.

Subsequently, samples were cut to perform the tests required to determine the mechanical, physical, and thermal properties of each of the 12 types of boards that were studied, with the appropriate dimensions as specified in the European standards [24] (Figure 1).

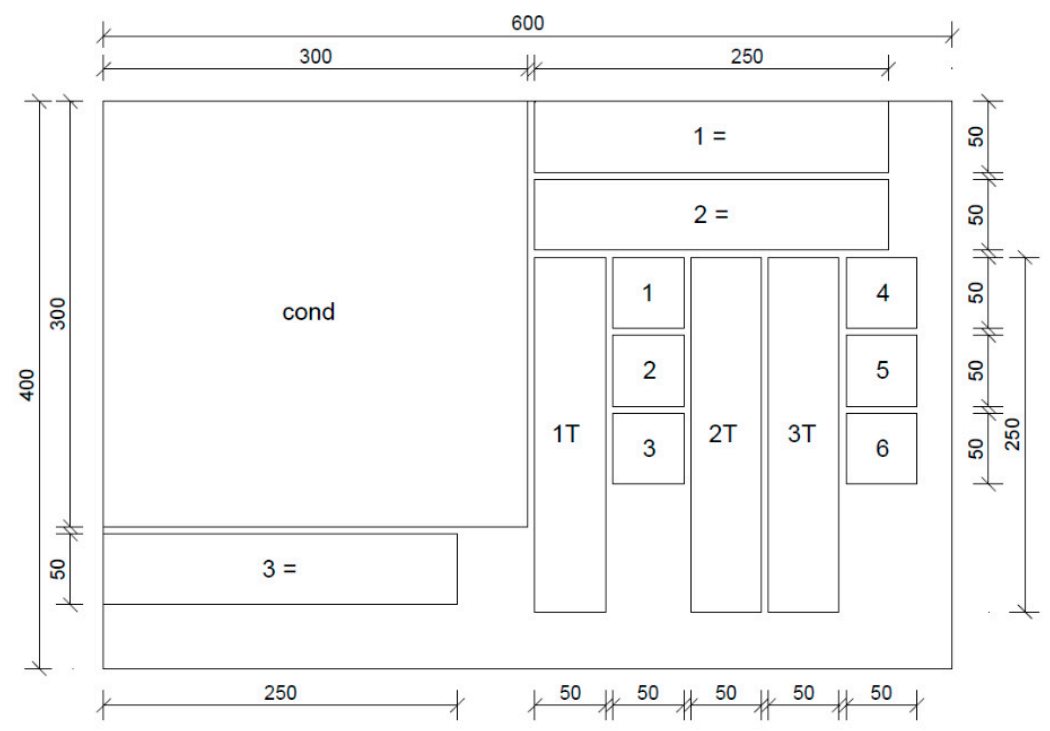

Figure 1. Cutting scheme of particleboards (lengths in $\mathrm{mm}$ ).

Preliminary tests were carried out to find out which tests were necessary, using the simplified equation of the Cochran and Cox method for repeated measures. Four panels were manufactured for each type. The characteristics of each type of particleboard are shown in Table 1.

Table 1. Types of boards manufactured.

\begin{tabular}{|c|c|c|c|c|c|}
\hline \multirow[t]{2}{*}{ Type of Board } & \multirow[t]{2}{*}{ No. of Boards } & \multirow[t]{2}{*}{ Density $\left(\mathrm{kg} / \mathrm{m}^{3}\right)$} & \multirow[t]{2}{*}{ Time (min) } & \multicolumn{2}{|c|}{$\begin{array}{l}\text { Weight Dosage (g/100 g of } \\
\text { Giant Reed Particles) }\end{array}$} \\
\hline & & & & Water & Citric Acid \\
\hline A1 & 4 & 600 & 7 & 10 & 5 \\
\hline A2 & 4 & 650 & 7 & 10 & 5 \\
\hline A3 & 4 & 700 & 7 & 10 & 5 \\
\hline A4 & 4 & 750 & 7 & 10 & 5 \\
\hline A5 & 4 & 800 & 7 & 10 & 5 \\
\hline A6 & 4 & 850 & 7 & 10 & 5 \\
\hline B1 & 4 & 600 & 7 & 10 & 10 \\
\hline B2 & 4 & 650 & 7 & 10 & 10 \\
\hline B3 & 4 & 700 & 7 & 10 & 10 \\
\hline B4 & 4 & 750 & 7 & 10 & 10 \\
\hline B5 & 4 & 800 & 7 & 10 & 10 \\
\hline B6 & 4 & 850 & 7 & 10 & 10 \\
\hline
\end{tabular}

Figure 2 shows some manufactured particleboards. 


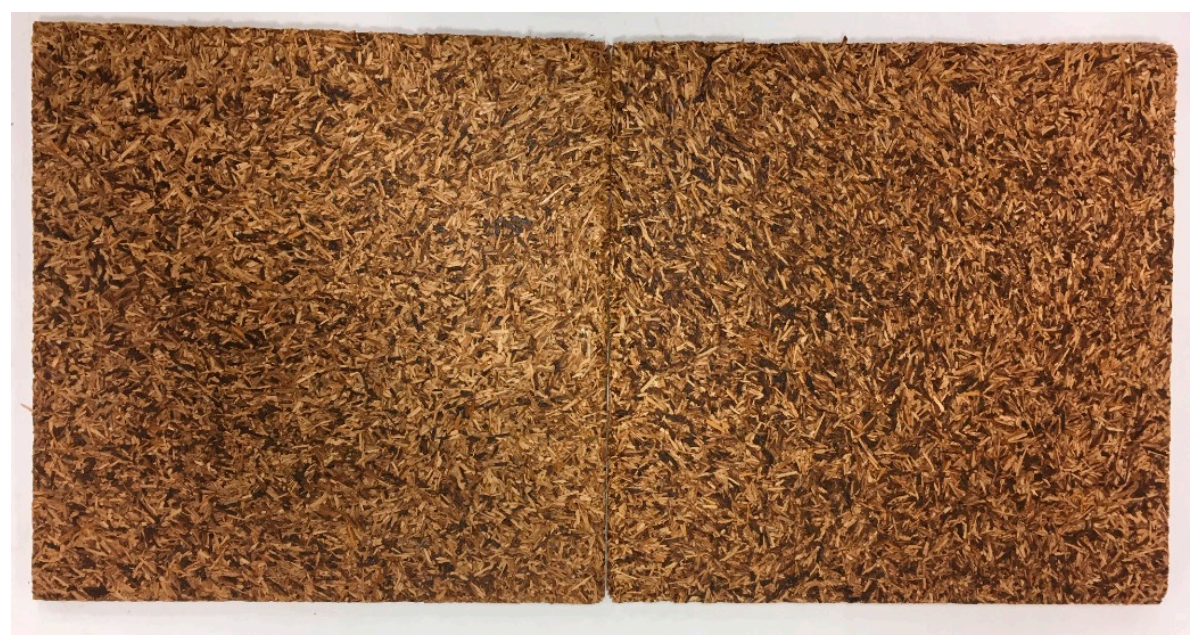

Figure 2. Giant reed particleboards with citric acid.

\subsubsection{Tests Performed}

The particleboards' properties were evaluated by means of experimental testing carried out in the material strength laboratory. Their properties were determined according to the European standards established for wooden particleboards [25].

The properties of the boards were measured according to the European standards: density [26], thickness swelling (TS), and water absorption (WA) after 2 and $24 \mathrm{~h}$ immersed in water [27], internal bonding strength (IB) [28], modulus of rupture (MOR), and modulus of elasticity (MOE) [29].

The density tests were performed using 6 samples from each board measuring $50 \times 50 \times 10 \mathrm{~mm}$ and the TS and WA tests were performed with three samples from each board measuring $50 \times 50 \times 10$ $\mathrm{mm}$, obtained from the outer and inner parts of the board.

Mechanical tests were performed with the IMAL testing machine (Model IB600), which complies with the constant velocity required for each test, as specified in the applicable European standards. Bending tests were carried out on six samples from each board (three in a longitudinal direction and three in a transversal direction) measuring $250 \times 50 \times 10 \mathrm{~mm}$, with a test speed of $5 \mathrm{~mm} / \mathrm{min}$. IB tests were performed on three samples from each board measuring $50 \times 50 \times 10 \mathrm{~mm}$, taken from the outer and inner parts of the board, using a constant speed of $2 \mathrm{~mm} / \mathrm{min}$.

The conductivity was measured using the heat flow meter method [30]. Thermal tests were performed with a heat flow meter from NETZSCH Instruments Inc., USA. A sample of dimensions $300 \times 300 \times 10 \mathrm{~mm}$ from each board was used for this test. The standard deviation was obtained from the mean values of the tests. In order to verify that the data obtained fulfil the requirement of normality, the Shapiro-Wilks test $(n<50)$ was performed. As a test of significance to verify that the data are appropriate for the model and to find out whether the sample is representative of the study population and there is homogeneity of variances, Bartlett's test was performed based on the analysis of residuals to test for non-normality. Finally, the results of the analysis of interaction are presented for the two-way ANOVA. The statistical analysis was performed using SPSS v.25.0 software from IBM, Armonk, New York, USA.

\section{Results and Discussion}

\subsection{Physical Properties}

Table 2 shows the mean densities obtained for six samples from each board. 
Table 2. Mean densities of the boards manufactured.

\begin{tabular}{ccccccccccccc}
\hline Type of Board & A1 & B1 & A2 & B2 & A3 & B3 & A4 & B4 & A5 & B5 & A6 & B6 \\
\hline Nominal density $\left(\mathrm{kg} / \mathrm{m}^{3}\right)$ & 600 & 600 & 650 & 650 & 700 & 700 & 750 & 750 & 800 & 800 & 850 & 850 \\
\% citric acid & 5 & 10 & 5 & 10 & 5 & 10 & 5 & 10 & 5 & 10 & 5 & 10 \\
Mean density $\left(\mathrm{kg} / \mathrm{m}^{3}\right)$ & 599.8 & 601.1 & 650.2 & 652.0 & 697.7 & 698.2 & 751.4 & 750.1 & 798.3 & 802.3 & 848.0 & 852.8 \\
Standard deviation & 8.52 & 5.52 & 8.28 & 4.74 & 1.15 & 13.30 & 9.63 & 7.07 & 6.65 & 10.53 & 2.00 & 9.91 \\
\hline
\end{tabular}

The results of the thickness swelling test are shown in Figure 3. The boards with a density of 600 and $650 \mathrm{~kg} / \mathrm{m}^{3}$ manufactured with $5 \%$ by weight of citric acid disintegrated in the water in less than $2 \mathrm{~h}$ and those with a density of $600 \mathrm{~kg} / \mathrm{m}^{3}$ manufactured with $10 \%$ by weight of citric acid deteriorated in less than $24 \mathrm{~h}$, so it would be necessary to add some kind of water repellent product to improve their water resistance.
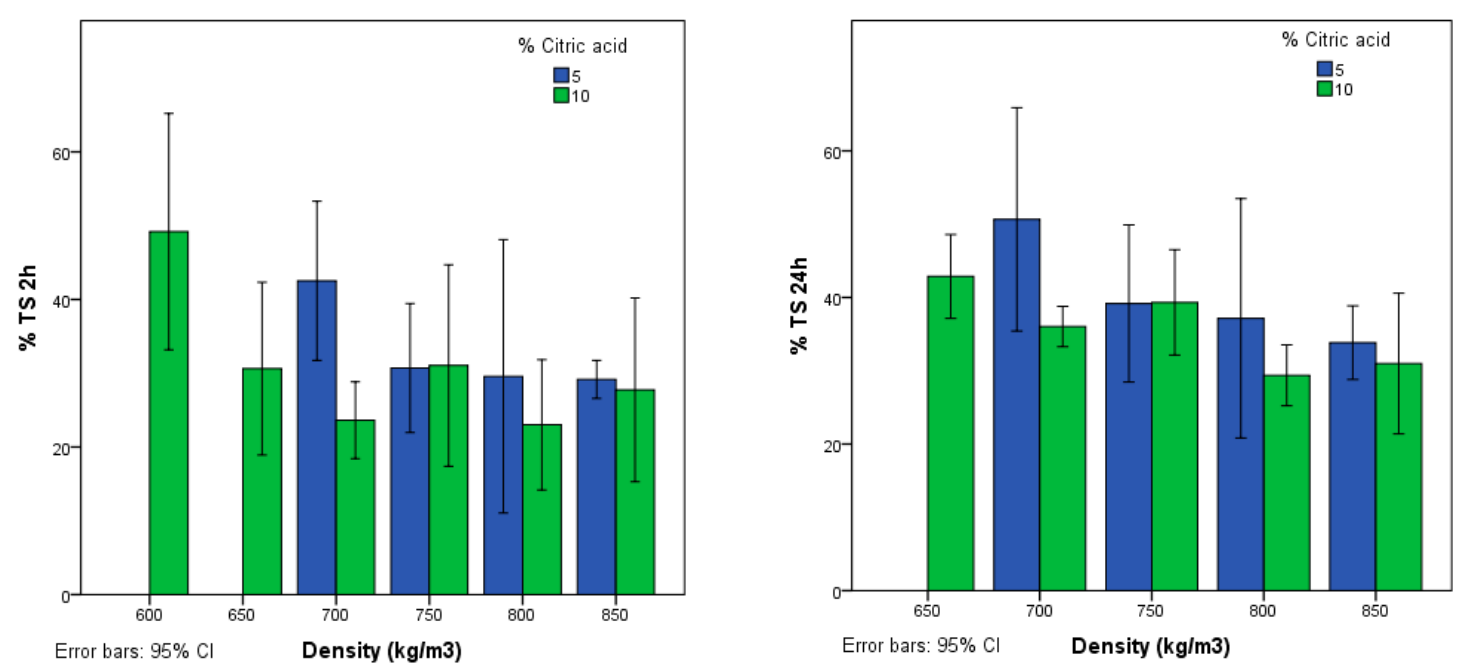

Figure 3. Thickness swelling (\%) after 2 and $24 \mathrm{~h}$ according to type of board.

After $2 \mathrm{~h}$ of immersion in water there was a large variability of values, since some samples were from the inner part of the board and others were from the outer part. In the test after $24 \mathrm{~h}$, it can be observed that the TS depended on the density and the percentage of citric acid added. Better properties were obtained with greater density and a higher proportion of citric acid, as the boards swelled less.

As can be seen in Figure 4, there were significant differences between the nine types of boards in terms of their water absorption behaviour after immersion. The WA depended on the density and the percentage of citric acid added; the greater the proportion, the lower the WA. The boards that absorbed the least water were type B6, with a WA of $57.30 \%$, and the type that absorbed the most water was A3, with a WA of $88.16 \%$. Type A1, A2 and B1 boards with $5 \%$ by weight of citric acid disintegrated in the water in less than $24 \mathrm{~h}$. The 600 and $650 \mathrm{~kg} / \mathrm{m}^{3}$ boards not only had a small amount of citric acid, they also had a smaller number of particles than the other boards. This means that air voids formed inside them, allowing water to enter the board and causing the particles to swell up, thereby breaking the bonds. Different water-repellent substances are added to commercial particleboards to increase their stability against water, but such substances were not used in this work. 

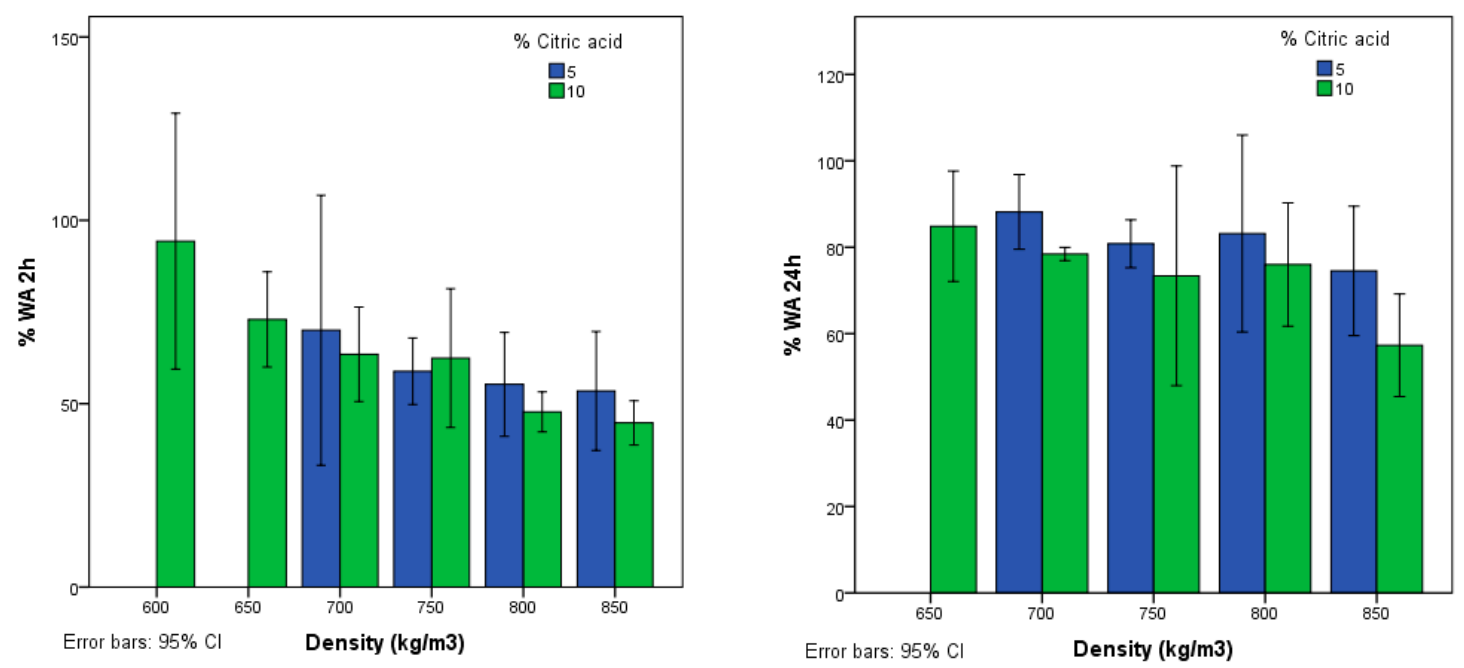

Figure 4. Water absorption (\%) after 2 and $24 \mathrm{~h}$ of immersion according to type of board.

Table 3 shows the data obtained in the Shapiro-Wilks test. With regard to Bartlett's test, assuming a risk of $0.5 \%$ (sig. $=0.005$ ) and 1 degree of freedom (d.f. $=1)$, the critical Chi-square value is 7.879 . As can be seen in Table 4, for all the tests carried out the calculated Chi-square value is higher than the critical Chi-square value obtained. Therefore, the null hypothesis that proposes that the variables are independent is rejected. With a confidence level above $99.5 \%$ the test shows that all the properties evaluated are dependent on the type of board manufactured. After verifying that the variables are dependent, that the distribution of the residuals is normal and that there is homogeneity of the variances, the analysis of variance (ANOVA) was performed with respect to the density and the $\%$ of citric acid (Table 5).

Table 3. Shapiro-Wilks test.

\begin{tabular}{|c|c|c|c|c|c|c|c|c|}
\hline Properties & Type of Board & Est. & d.f. & Sig. & Type of Board & Est. & d.f. & Sig. \\
\hline TS 24 h (\%) & & - & - & - & & - & - & - \\
\hline WA 24 h (\%) & & - & - & - & & - & - & - \\
\hline $\operatorname{MOR}\left(\mathrm{N} / \mathrm{mm}^{2}\right)$ & & 0.908 & 4 & 0.424 & & 0.989 & 4 & 0.952 \\
\hline $\operatorname{MOE}\left(\mathrm{N} / \mathrm{mm}^{2}\right)$ & A1 & 0.921 & 4 & 0.479 & B1 & 0.997 & 4 & 0.989 \\
\hline $\mathrm{IB}\left(\mathrm{N} / \mathrm{mm}^{2}\right)$ & & 0.960 & 4 & 0.819 & & 0.920 & 4 & 0.538 \\
\hline Thermal C. $(\mathrm{W} / \mathrm{m} \cdot \mathrm{K})$ & & 0.923 & 8 & 0.456 & & 0.925 & 8 & 0.470 \\
\hline Thermal R. $\left(\mathrm{m}^{2} \cdot \mathrm{K} / \mathrm{m}\right)$ & & 0.911 & 8 & 0.360 & & 0.904 & 8 & 0.316 \\
\hline TS $24 \mathrm{~h}(\%)$ & & - & - & - & & 0.987 & 12 & 0.785 \\
\hline WA 24 h (\%) & & - & - & - & & 0.964 & 12 & 0.637 \\
\hline $\operatorname{MOR}\left(\mathrm{N} / \mathrm{mm}^{2}\right)$ & & 0.990 & 4 & 0.890 & & 0.962 & 4 & 0.627 \\
\hline $\operatorname{MOE}\left(\mathrm{N} / \mathrm{mm}^{2}\right)$ & $\mathrm{A} 2$ & 0.881 & 4 & 0.328 & B2 & 0.941 & 4 & 0.663 \\
\hline IB $\left(\mathrm{N} / \mathrm{mm}^{2}\right)$ & & 0.990 & 4 & 0.900 & & 0.855 & 4 & 0.253 \\
\hline Thermal C. $(\mathrm{W} / \mathrm{m} \cdot \mathrm{K})$ & & 0.924 & 8 & 0.505 & & 0.888 & 8 & 0.225 \\
\hline Thermal R. $\left(\mathrm{m}^{2} \cdot \mathrm{K} / \mathrm{m}\right)$ & & 0.933 & 8 & 0.579 & & 0.862 & 8 & 0.126 \\
\hline TS 24 h (\%) & & 0.968 & 12 & 0.859 & & 0.824 & 12 & 0.073 \\
\hline WA 24 h (\%) & & 0.833 & 12 & 0.145 & & 0.798 & 12 & 0.057 \\
\hline $\operatorname{MOR}\left(\mathrm{N} / \mathrm{mm}^{2}\right)$ & & 0.883 & 4 & 0.334 & & 0.945 & 4 & 0.684 \\
\hline $\operatorname{MOE}\left(\mathrm{N} / \mathrm{mm}^{2}\right)$ & $\mathrm{A} 3$ & 0.868 & 4 & 0.290 & B3 & 0.984 & 4 & 0.758 \\
\hline $\mathrm{IB}\left(\mathrm{N} / \mathrm{mm}^{2}\right)$ & & 0.881 & 4 & 0.328 & & 0.860 & 4 & 0.262 \\
\hline Thermal C. $(\mathrm{W} / \mathrm{m} \cdot \mathrm{K})$ & & 0.884 & 8 & 0.174 & & 0.856 & 8 & 0.108 \\
\hline Thermal R. $\left(\mathrm{m}^{2} \cdot \mathrm{K} / \mathrm{m}\right)$ & & 0.870 & 8 & 0.123 & & 0.848 & 8 & 0.090 \\
\hline
\end{tabular}


Table 3. Cont.

\begin{tabular}{|c|c|c|c|c|c|c|c|c|}
\hline Properties & Type of Board & Est. & d.f. & Sig. & Type of Board & Est. & d.f. & Sig. \\
\hline TS 24 h (\%) & & 0.951 & 12 & 0.573 & & 0.972 & 12 & 0.853 \\
\hline WA 24 h (\%) & & 0.876 & 12 & 0.313 & & 0.824 & 12 & 0.153 \\
\hline $\operatorname{MOR}\left(\mathrm{N} / \mathrm{mm}^{2}\right)$ & & 0.936 & 4 & 0.641 & & 0.839 & 4 & 0.191 \\
\hline $\operatorname{MOE}\left(\mathrm{N} / \mathrm{mm}^{2}\right)$ & A4 & 0.920 & 4 & 0.502 & B4 & 0.805 & 4 & 0.112 \\
\hline IB $\left(\mathrm{N} / \mathrm{mm}^{2}\right)$ & & 0.836 & 4 & 0.154 & & 0.854 & 4 & 0.240 \\
\hline Thermal C. $(\mathrm{W} / \mathrm{m} \cdot \mathrm{K})$ & & 0.872 & 8 & 0.130 & & 0.929 & 8 & 0.542 \\
\hline Thermal R. $\left(\mathrm{m}^{2} \cdot \mathrm{K} / \mathrm{m}\right)$ & & 0.850 & 8 & 0.075 & & 0.929 & 8 & 0.544 \\
\hline TS 24 h (\%) & & 0.960 & 12 & 0.818 & & 1.000 & 12 & 0.988 \\
\hline WA 24 h (\%) & & 0.824 & 12 & 0.096 & & 0.878 & 12 & 0.319 \\
\hline $\operatorname{MOR}\left(\mathrm{N} / \mathrm{mm}^{2}\right)$ & & 0.918 & 4 & 0.446 & & 0.977 & 4 & 0.706 \\
\hline $\operatorname{MOE}\left(\mathrm{N} / \mathrm{mm}^{2}\right)$ & A5 & 0.794 & 4 & 0.054 & B5 & 0.824 & 4 & 0.202 \\
\hline IB $\left(\mathrm{N} / \mathrm{mm}^{2}\right)$ & & 0.923 & 4 & 0.463 & & 0.923 & 4 & 0.463 \\
\hline Thermal C. $(\mathrm{W} / \mathrm{m} \cdot \mathrm{K})$ & & 0.891 & 8 & 0.239 & & 0.870 & 8 & 0.150 \\
\hline Thermal R. $\left(\mathrm{m}^{2} \cdot \mathrm{K} / \mathrm{m}\right)$ & & 0.887 & 8 & 0.222 & & 0.870 & 8 & 0.149 \\
\hline TS 24 h (\%) & & 0.914 & 12 & 0.502 & & 0.861 & 12 & 0.094 \\
\hline WA 24 h (\%) & & 0.904 & 12 & 0.450 & & 0.812 & 12 & 0.058 \\
\hline $\operatorname{MOR}\left(\mathrm{N} / \mathrm{mm}^{2}\right)$ & & 0.917 & 4 & 0.484 & & 0.967 & 4 & 0.824 \\
\hline $\operatorname{MOE}\left(\mathrm{N} / \mathrm{mm}^{2}\right)$ & A6 & 0.943 & 4 & 0.686 & B6 & 0.803 & 4 & 0.055 \\
\hline IB $\left(\mathrm{N} / \mathrm{mm}^{2}\right)$ & & 0.864 & 4 & 0.203 & & 0.863 & 4 & 0.272 \\
\hline Thermal C. $(\mathrm{W} / \mathrm{m} \cdot \mathrm{K})$ & & 0.938 & 8 & 0.591 & & 0.877 & 8 & 0.178 \\
\hline Thermal R. $\left(\mathrm{m}^{2} \cdot \mathrm{K} / \mathrm{m}\right)$ & & 0.987 & 8 & 0.989 & & 0.886 & 8 & 0.216 \\
\hline
\end{tabular}

Est.: statistical digit. d.f.: degrees of freedom. Sig.: significance.

Table 4. Bartlett's test.

\begin{tabular}{ccccc}
\hline Factor & Properties & Chi Square Test & d.f. & Sig. \\
\hline \multirow{5}{*}{ Type of board } & TS $24 \mathrm{~h}(\%)$ & 23.648 & 1 & 0.010 \\
& WA $24 \mathrm{~h}(\%)$ & 17.562 & 1 & 0.000 \\
& MOR $\left(\mathrm{N} / \mathrm{mm}^{2}\right)$ & 73.133 & 1 & 0.000 \\
& MOE $\left(\mathrm{N} / \mathrm{mm}^{2}\right)$ & 75.683 & 1 & 0.000 \\
& IB $\left(\mathrm{N} / \mathrm{mm}^{2}\right)$ & 64.666 & 1 & 0.000 \\
& Thermal C. $(\mathrm{W} / \mathrm{m} \cdot \mathrm{K})$ & 57.693 & 1 & 0.000 \\
& Thermal R. $\left(\mathrm{m}^{2} \cdot \mathrm{K} / \mathrm{m}\right)$ & 53.562 & 1 & 0.000 \\
\hline
\end{tabular}

d.f.: degrees of freedom. Sig.: significance.

Table 5. ANOVA of the results of the tests.

\begin{tabular}{ccccccc}
\hline Factor & Properties & Sum of Squares & d.f. & Half Quadratic & F & Sig. \\
\hline \multirow{5}{*}{ Density } & TS 24 h (\%) & 572.194 & 4 & 143.049 & 13.288 & 0.010 \\
& WA 24 h (\%) & 1707.324 & 4 & 426.831 & 24.638 & 0.000 \\
& MOR $\left(\mathrm{N} / \mathrm{mm}^{2}\right)$ & 2414.023 & 5 & 482.805 & 185.124 & 0.000 \\
& MOE $\left(\mathrm{N} / \mathrm{mm}^{2}\right)$ & $102,056,125.670$ & 5 & $20,411,225.134$ & 123.329 & 0.000 \\
& IB $\left(\mathrm{N} / \mathrm{mm}^{2}\right)$ & 4.599 & 5 & 0.920 & 4.919 & 0.000 \\
& Thermal C. $(\mathrm{W} / \mathrm{m} \cdot \mathrm{K})$ & 0.002 & 5 & 0.000 & 12.823 & 0.000 \\
& Thermal R. $\left(\mathrm{m}^{2} \cdot \mathrm{K} / \mathrm{m}\right)$ & 0.003 & 5 & 0.001 & 12.310 & 0.000 \\
\hline \multirow{5}{*}{ Citric acid } & TS $24 \mathrm{~h}(\%)$ & 156.228 & 1 & 156.228 & 11.327 & 0.041 \\
& WA $24 \mathrm{~h}(\%)$ & 402.457 & 1 & 402.457 & 13.809 & 0.028 \\
& MOR $\left(\mathrm{N} / \mathrm{mm}^{2}\right)$ & 287.215 & 1 & 287.215 & 28.698 & 0.000 \\
& MOE $\left(\mathrm{N} / \mathrm{mm}^{2}\right)$ & $9,294,145.327$ & 1 & $9,294,145.327$ & 17.803 & 0.000 \\
& IB $\left(\mathrm{N} / \mathrm{mm}^{2}\right)$ & 0.255 & 1 & 0.255 & 5.205 & 0.048 \\
& Thermal C. $(\mathrm{W} / \mathrm{m} \cdot \mathrm{K})$ & 0.000 & 1 & 0.000 & 0.857 & 0.357 \\
& Thermal R. $\left(\mathrm{m}^{2} \cdot \mathrm{K} / \mathrm{m}\right)$ & 0.000 & 1 & 0.000 & 0.059 & 0.334 \\
\hline
\end{tabular}


The Shapiro-Wilks test (Table 3) for each type of board was performed with the data obtained from 144 tests after $2 \mathrm{~h}$ and 108 after $24 \mathrm{~h}$. The value associated with the statistical digit has a significance of $>0.05$ for each type of board, thus corroborating the hypothesis of homogeneity of variances of the data obtained for TS and WA after $24 \mathrm{~h}$ of immersion in water. Bartlett's test for TS and WA (Table 4) with a significance level of $<0.05$ indicates that the variances are equal and factor analysis can be applied. To verify whether TS and WA depended on the density or the percentage of citric acid, ANOVA was performed (Table 5) for all the tests carried out (108 tests, as it was not possible to test types A1, B1, and $\mathrm{A} 2$ after $24 \mathrm{~h}$ ).

\subsection{Mechanical Properties}

As can be seen in Table 3, the data obtained for MOR, MOE, and IB fulfil the assumption of normality for each type of board, as they have a significance level of $>0.05$.

Bartlett's test (Table 4) for MOR, MOE, and IB with a significance level of $<0.05$ indicates that the variances are equal. To verify whether MOR, MOE, and IB depended on the density and the percentage of citric acid, ANOVA was performed for the tests carried out ( 288 bending tests and 144 traction tests).

Table 5 shows that MOR, MOE, and IB depend on the density and the $\%$ of citric acid. Bending test results are shown in Figures 5 and 6 and the MOR values obtained ranged from $1.7 \mathrm{~N} / \mathrm{mm}^{2}$ to $12.5 \mathrm{~N} / \mathrm{mm}^{2}$. It can be seen that the MOR values tended to increase with density. In fact, the worse performances were obtained with the $600 \mathrm{~kg} / \mathrm{m}^{3}$ particleboards. It is also interesting to note that the greater the citric acid content, the higher the MOR value.

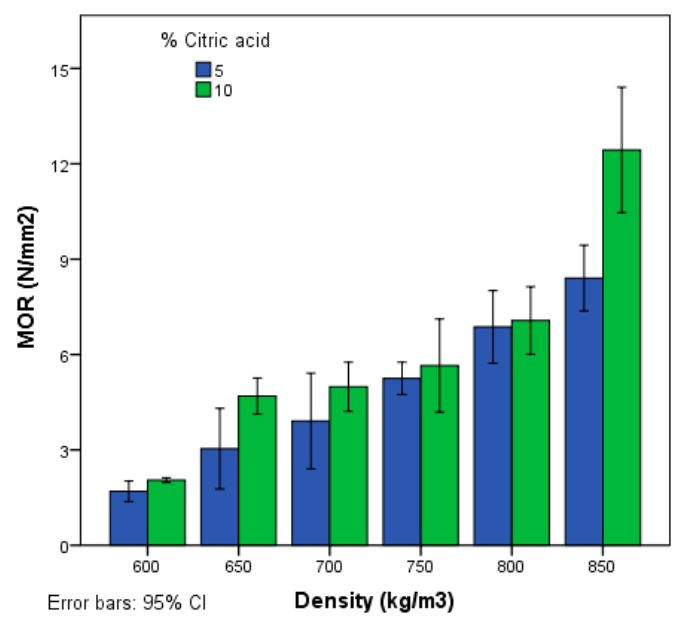

Figure 5. Modulus of rupture according to type of board.

Figure 6 shows the values obtained for the modulus of elasticity (MOE), which depends on the citric acid content and density. The MOE varies greatly from one type of board to another, ranging from $260 \mathrm{~N} \cdot \mathrm{mm}^{-2}$ to $2440 \mathrm{~N} \cdot \mathrm{mm}^{-2}$. Density strongly influences the MOE value. The MOR and MOE values obtained are not very high, as better properties have been achieved using giant reed biomass with urea-formaldehyde resin [31]. However, it must be considered that this synthetic resin is toxic and that in this work boards were manufactured with natural products that are entirely eco-friendly and biodegradable.

Increasing the \% of citric acid favours particle binding, possibly due to the chemical reaction between the hydroxyl groups of the giant reed and the carboxyl groups of the citric acid. Thus, a larger number of particles in the board will result in better mechanical properties. The great difference in MOR and MOE values between the different types of board tested can be explained by the fact that the higher the density, the greater the number of particles. Likewise, the boards with a lower density have a larger number of air voids, meaning that they have a lower particle content to resist stress. 


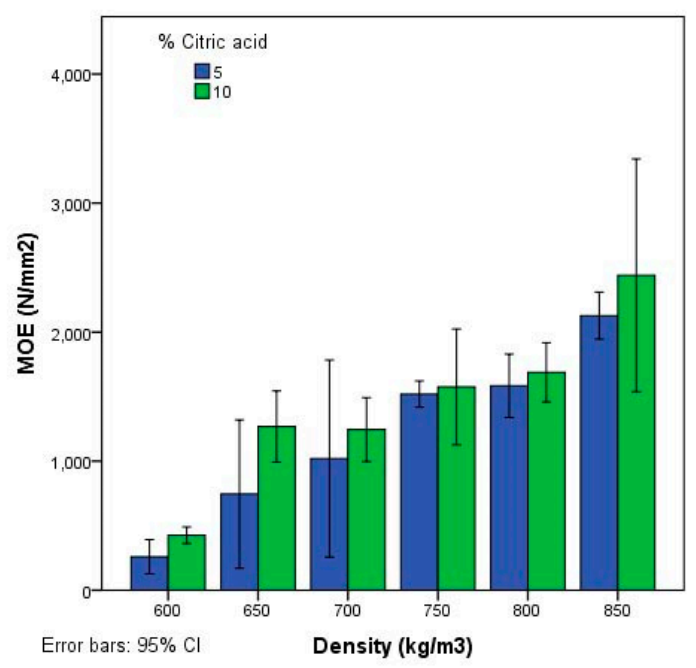

Figure 6. Modulus of elasticity according to type of board.

The internal bonding strength (IB) values are shown in Figure 7, and it can be seen that they increase with greater densities and in proportion to the citric acid added. The average value for type B5 boards is $0.61 \mathrm{~N} \cdot \mathrm{mm}^{-2}$ and for type A1 boards, $0.07 \mathrm{~N} \cdot \mathrm{mm}^{-2}$.

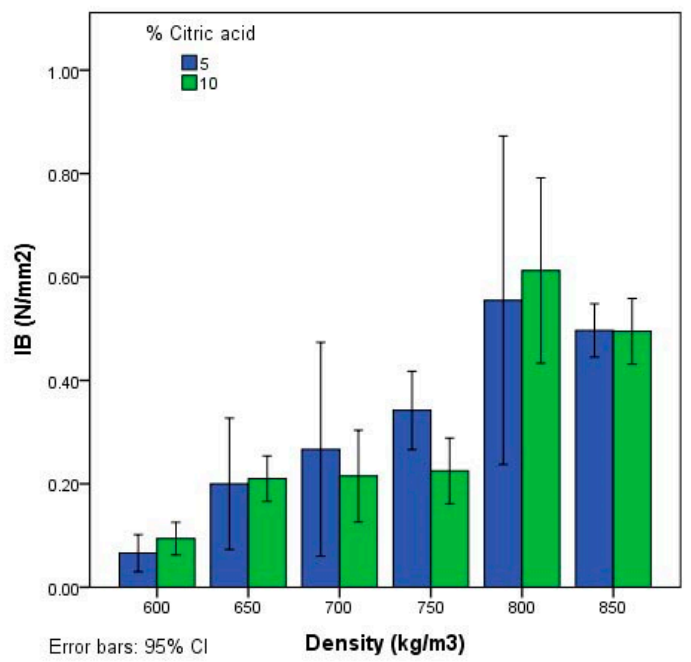

Figure 7. Internal bonding strength according to type of board.

Table 6 shows a comparison of the results obtained with the values required by the European standards [32] to determine the compatibility of uses of boards with a thickness of 6 to $13 \mathrm{~mm}$.

The type $\mathrm{B} 6$ board could be classified as P2, non-structural boards for indoor use in furniture manufacture. It cannot be classified as P3, structural board for outdoor use, because the necessary MOR and MOE values are not reached. 
Table 6. Characteristics of the type of panels manufactured and classification.

\begin{tabular}{|c|c|c|c|c|}
\hline Type of Board & $\operatorname{MOR}\left(\mathrm{N} / \mathrm{mm}^{2}\right)$ & $\operatorname{MOE}\left(\mathrm{N} / \mathrm{mm}^{2}\right)$ & IB $\left(\mathrm{N} / \mathrm{mm}^{2}\right)$ & TS $24 \mathrm{~h}(\%)$ \\
\hline A1 & 1.70 & 259.97 & 0.07 & \\
\hline $\mathrm{A} 2$ & 3.04 & 745.44 & 0.20 & \\
\hline A3 & 3.91 & 1019.80 & 0.27 & 38.99 \\
\hline $\mathrm{A} 4$ & 5.25 & 1519.30 & 0.34 & 29.17 \\
\hline A5 & 6.87 & 1584.58 & 0.56 & 27.16 \\
\hline A6 & 8.41 & 2127.53 & 0.52 & 23.84 \\
\hline B1 & 2.05 & 426.08 & 0.09 & \\
\hline $\mathrm{B} 2$ & 4.70 & $1,267.95$ & 0.21 & 32.87 \\
\hline B3 & 4.99 & $1,244.61$ & 0.22 & 26.03 \\
\hline $\mathrm{B} 4$ & 5.66 & $1,575,24$ & 0.33 & 24.33 \\
\hline B5 & 8.07 & $1,688.22$ & 0.61 & 19.37 \\
\hline B6 & 12.51 & $2,439.94$ & 0.54 & 17.98 \\
\hline Type P1 [32] & 10.50 & - & 0.28 & - \\
\hline Type P2 [32] & 11.00 & $1,800.00$ & 0.40 & - \\
\hline Type P3 [32] & 15.00 & $2,050.00$ & 0.45 & 17.00 \\
\hline
\end{tabular}

\subsection{Thermal Properties}

Two thermal conductivity and resistance tests were carried out per board and statistical analysis was performed (Tables 3-5).

The Shapiro-Wilks test has a significance level of $>0.05$ for all the types of board (Table 3), so they have equal variances. In general, the data obtained follow a normal distribution for each type of board.

Bartlett's test for thermal conductivity and thermal resistance with a significance level of $<0.05$ (Table 4) indicates that the variances are equal and factor analysis can be applied.

Table 5 showing ANOVA with a significance level of $<0.05$ indicates that the thermal conductivity and resistance depended on the density, although the thermal properties did not depend on the $\%$ of citric acid. Figure 8 summarises the average thermal conductivity values obtained for all particleboards. The values obtained ranged from 0.081 to $0.093 \mathrm{~W} \cdot \mathrm{m}^{-1} \cdot \mathrm{K}^{-1}$ and this means that these materials can be used for thermal insulation. As the density increased, the thermal conductivity increased and the thermal resistance decreased. Therefore, the boards with the lowest density had better thermal properties, which could be attributed to the greater amount of air inside them.
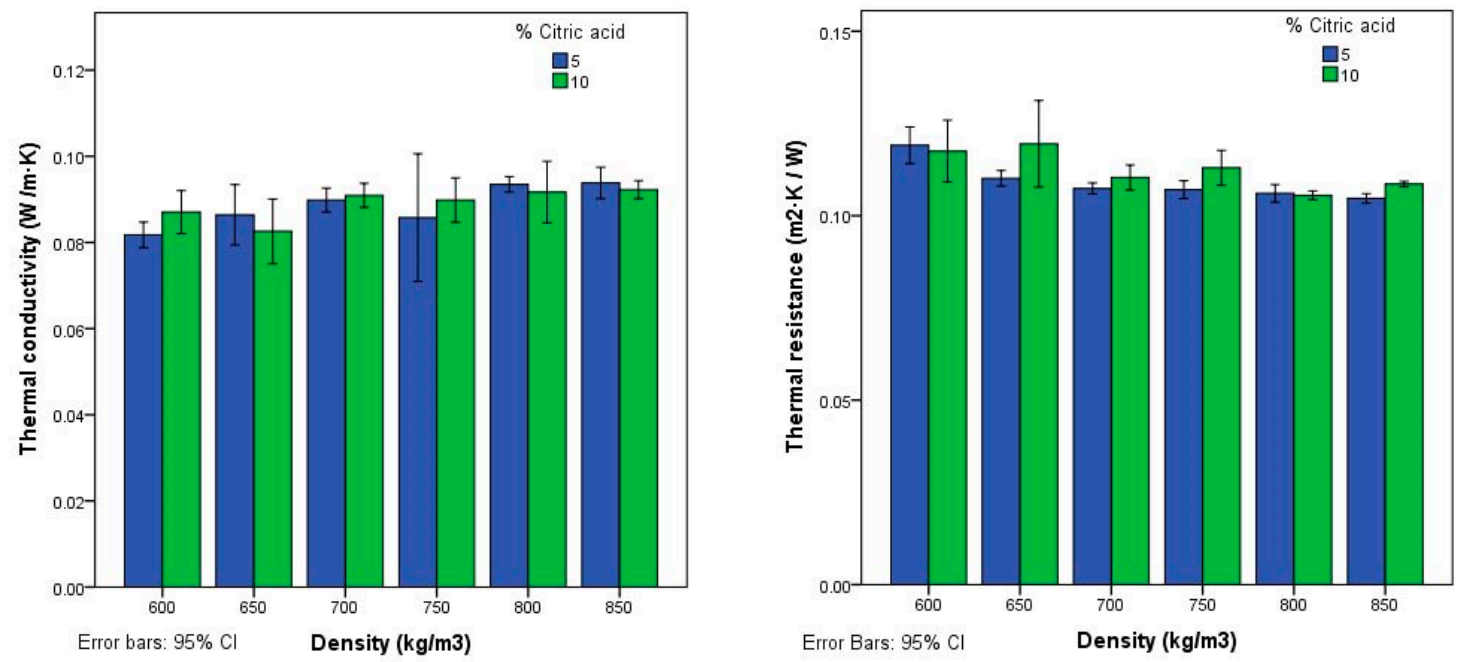

Figure 8. Thermal conductivity and resistance according to type of board. 
As MOR, MOE, IB, and TS depend on the $\%$ of citric acid, it is possible to produce good insulating panels with good physical and mechanical properties with low-density boards by increasing the $\%$ of citric acid used to produce the boards, which needs to be tested.

Table 7 compares the thermal conductivity values obtained by other authors with other plant fibers. In tests with boards of similar densities to those of our study, similar values were obtained.

Table 7. Thermal conductivity coefficients obtained in tests with different organic fibers.

\begin{tabular}{ccc}
\hline Name & Thermal Conductivity $\boldsymbol{\lambda}(\mathbf{W} / \mathbf{m}$ K) & Source \\
\hline Hemp & 0.111 & {$[7]$} \\
Flax & 0.040 to 0.094 & {$[11]$} \\
Cotton & 0.035 to 0.075 & {$[11]$} \\
Date palm rachis & 0.042 & {$[1]$} \\
Rice straw & 0.040 to 0.069 & {$[33]$} \\
Sisal & 0.083 & {$[34]$} \\
Sugarcane bagasse & 0.078 to 0.090 & {$[12]$} \\
Woodchip panels & 0.070 & {$[13]$} \\
Giant reed with citric acid & 0.075 & {$[35]$} \\
\hline
\end{tabular}

The natural materials that are used commercially (flax, hemp, cotton, etc.) had better thermal properties than the boards obtained in this work, but these materials are only pressed and they do not have any mechanical strength, so they are used as a filler or coated with other stronger materials. Furthermore, giant reed is a waste product, a contaminating weed, while other natural materials can be used for other applications.

Commercial rigid wood fiber insulation boards have a similar thermal conductivity to the boards obtained in this work, but they are manufactured using urea-formaldehyde as an adhesive, which can be carcinogenic and its use is becoming increasingly limited. Moreover, giant reed particleboards using a natural adhesive have better mechanical properties than commercial wood fiber insulation boards.

Citric acid can be a good adhesive because esterification takes place during the particleboard production process [14]. Based on the results obtained in this work, it is assumed that the giant reed particles are bonded, but it is necessary to continue investigating this type of adhesive to try to improve its properties.

Type B6 boards have properties of non-structural boards, for indoor use in furniture manufacture [35], especially kitchen furniture due to its good water resistance. They also offer good thermal properties, meaning that they could be used to construct interior divisions in buildings without the need for coatings. Therefore, with the right manufacturing conditions, it would be possible to produce giant reed particleboards with citric acid that offer good resistance and insulating properties.

\section{Conclusions}

Based on the mechanical and thermal properties obtained in this work, it can be stated that all the particleboards could be used as insulating material.

The type B6 boards could be used inside buildings as a dividing element and for manufacturing furniture.

It can be concluded from the results obtained that the boards with $10 \%$ by weight of citric acid may offer better performance against water. Considering that the MOR, MOE, IB and TS depend on the $\%$ of citric acid, future research could focus on seeking the right dosages to achieve boards with suitable properties for outdoor use.

The boards with $10 \%$ by weight of citric acid perform well against water. Given that the MOR, MOE, IB, and TS depend on the \% of citric acid, it would be possible to produce boards with suitable properties for outdoor use. 
Bonding of the particles may be due to changes in the chemical components (esterification) of the giant reed during treatment in the hot plate press and to the chemical reaction between the hydroxyl groups in the giant reed and the carboxyl groups in the citric acid.

Resistant boards with good insulating properties can be manufactured using two natural biodegradable products: giant reed and citric acid.

The production of the boards in this work consumes less energy than that of industrial particleboards. In order to manufacture commercial particleboards with a dry process (such as the one used in this work), initially the material is left to air dry before being ground and dried in dryers. Wood particles are dried to $4 \% \mathrm{RH}$ and the particles in this work had an $\mathrm{RH}$ of $9 \%$. Commercial wood boards consume the same or a larger amount of energy in the grinding process, as the giant reed stems are easier to grind than a tree trunk. Finally, in our work it was not necessary to dry the material after grinding and the temperature of the press $\left(150^{\circ} \mathrm{C}\right)$ is lower than the temperature used in the manufacture of industrial particleboards $\left(180^{\circ} \mathrm{C}\right)$. Therefore, using giant reed waste to manufacture agglomerated particleboards has two advantages: on the one hand, it has environmental benefits and, on the other, the manufacturing process generates lower energy costs than those involved in conventional manufacturing of such products.

Author Contributions: M.T.F.-G. and C.E.F.-G. devised and designed the experiments; M.F.-V. and T.G.-O. performed the experiments; A.F.-G. and M.T.F.-G. analysed the data; M.F.-V. contributed reagents/materials/analytical tools; M.T.F.-G. wrote the first draft of the paper. All authors assisted in writing and improving the paper.

Funding: This research was funded by the Spanish Ministry of Economy, Industry and Competitiveness through the "Retos" programme, project AGL2013-41612-R.

Acknowledgments: The authors wish to acknowledge the support of the Spanish Ministry of Economy, Industry and Competitiveness through the "Retos" programme, project AGL2013-41612-R.

Conflicts of Interest: The authors declare no conflict of interest.

\section{References}

1. Alavez-Ramirez, R.; Chinas-Castillo, F.; Morales-Dominguez, V.J.; Ortiz-Guzman, M. Thermal conductivity of coconut fibre filled ferrocement sandwich panels. Constr. Build. Mater. 2012, 37, 425-431. [CrossRef]

2. Lertsutthiwong, P.; Khunthon, S.; Siralertmukul, K.; Noomun, K.; Chandrkrachang, S. New insulating particleboards prepared from mixture of solid wastes from tissue paper manufacturing and corn peel. Bioresour. Technol. 2008, 99, 4841-4845. [CrossRef] [PubMed]

3. Ardente, F.; Beccali, M.; Cellura, M.; Mistretta, M. Building energy performance: A LCA case study of kenaf-fibres insulation board. Energy Build. 2008, 40, 1-10. [CrossRef]

4. Zhou, X.Y.; Zheng, F.; Li, H.G.; Lu, C.L. An environment-friendly thermal insulation material from cotton stalk fibers. Energy Build. 2012, 42, 1070-1074. [CrossRef]

5. Ferrández-Garcia, M.T.; Ferrández-García, C.E.; Andreu-Rodriguez, J.; Ferrández-Villena, M.; García-Ortuño, T. The suitability of utilising cotton stalk for low cost binderless panels. In Actual Tasks on Agricultural Engineering, Proceedings of the 41 International Symposium on Agricultural Engineering, Opatija, Croatia, 19-22 February 2013; University of Zagreb Faculty of Agriculture: Opatija, Croatia, 2013; pp. 388-392.

6. Panyakaew, S.; Fotios, S. New thermal insulation boards made from coconut husk and bagasse. Energy Build. 2011, 43, 1732-1739. [CrossRef]

7. Behzad, T.; Sain, M. Measurement and prediction of thermal conductivity for hemp fiber reinforced composites. Polym. Eng. Sci. 2007, 47, 977-983. [CrossRef]

8. Benfratello, S.; Capitano, C.; Peri, G.; Rizzo, G.; Scaccianoce, G.; Sorrentino, G. Thermal and structural properties of a hemp-lime biocomposite. Constr. Build. Mater. 2013, 48, 745-754. [CrossRef]

9. Chikhi, M.; Agoudjil, B.; Boudenne, A.; Gherabli, A. Experimental investigation of new biocomposite with low cost for thermal insulation. Energy Build. 2013, 66, 267-273. [CrossRef]

10. Murphy, R.J.; Norton, A. Life Cycle Assessments of Natural Fibre Insulation Materials; National Non-Food Crops Centre-NNFCC: London, UK, 2008; p. 79. 
11. Kymalainen, H.R.; Sjoberg, A.M. Flax and Hemp Fibres as Raw Materials for Thermal Insulations; University of Helsinki, Department of Agrotechnology: Helsinki, Finland, 2008; pp. 1261-1269.

12. Ferrández-Garcia, C.C.; Garcia-Ortuño, T.; Ferrández-Garcia, M.T.; Ferrández-Villena, M.; Ferrández-García, C.E. Fire-resistance, Physical, and Mechanical Characterization of Binderless Rice Straw Particleboards. BioResources 2017, 12, 8539-8549.

13. Kalaprasad, G.; Pradeep, P.; Mathew, G.; Pavithran, C.; Thomas, S. Thermal conductivity and thermal diffusivity analyses of low-density polyethylene composites reinforced with sisal, glass and intimately mixed sisal/glass fibres. Compos. Sci. Technol. 2000, 60, 2967-2977. [CrossRef]

14. Liao, R.; Xu, J.; Umemura, K. Low density sugarcane bagasse particleboard bonded with citric acid and sucrose: Effect of board density and additive content. BioResources 2016, 11, 2174-2185. [CrossRef]

15. Ferrández-García, C.E.; Andreu-Rodríguez, J.; Ferrández-García, M.T.; Ferrández-Villena, M.; García-Ortuño, T. Panels made from giant reed bonded with non-modified starches. BioResources 2012, 7, 5904-5916. [CrossRef]

16. Ferrández García, C.C.; Ferrández-Villena, M.; Cuartero, J.; García-Ortuño, T.; Ferrández-García, M.T.; Andreu-Rodríguez, J. Manufacture and Properties of Three-Layered Low Density Particleboard from Giant Reed. In Structures and Environmental Technologies, Proceedings of the International Conference of Agricultural Engineering-CIGR-AgEng 2012: Agriculture and Engineering for A Healthier Life, Valencia, Spain, 8-12 July 2012; CIGR-EurAgEng: Valencia, Spain, 2012.

17. Ferrández-García, A.; Ferrández-Villena, M.; Ferrández-García, C.E.; García-Ortuño, T.; Ferrández-García, M.T. Potential Use of Phoenix canariensis Biomass in Binderless Particleboards at Low Temperature and Pressure. BioResources 2017, 12, 6698-6712. [CrossRef]

18. Ferrández-García, C.C.; Ferrández-García, C.E.; Ferrández-Villena, M.; Ferrandez-García, M.T.; García-Ortuño, T. Acoustic and Thermal Evaluation of Palm Panels as Building Material. BioResources 2017, 12, 8047-8057.

19. El Mansouri, N.E.; Salvadó, J. Structural characterization of technical lignins for the production of adhesives: Application to lignosulfonate, kraft, soda-anthraquinone, organosolv and ethanol process lignins. Ind. Crop. Prod. 2006, 24, 8-16. [CrossRef]

20. Guimarães Carvalho, A.; Costa Lelis, R.C.; do Nascimento, A.M. Avaliação de adesivos à base de taninos de Pinus caribaea var. bahamensis e de Acacia mearnsii na fabricação de painéis aglomerados. Cienc. Florest. 2014, 24, 479-489.

21. Umemura, K.; Sugihara, O.; Kawai, S. Investigation of a new natural adhesive composed of citric acid and sucrose for particleboard. J. Wood Sci. 2013, 59, 203-208. [CrossRef]

22. Widyorini, R.; Umemura, K.; Isnan, R.; Putra, D.R.; Awaludin, A.; Prayitno, T.A. Manufacture and properties of citric acid-bonded particleboard made from bamboo materials. Eur. J. Wood Wood Prod. 2016, 74, 57-65. [CrossRef]

23. Kusumah, S.S.; Umemura, K.; Yoshioka, K.; Miyafuji, H.; Kanayama, K. Utilization of sweet sorghum bagasse and citric acid for manufacturing of particleboard I: Effects of pre-drying treatment and citric acid content on the board properties. Ind. Crop. Prod. 2016, 84, 34-42. [CrossRef]

24. EN 326. Wood-Based Panels. In Sampling, Cutting and Inspection. Part 1: Sampling and Cutting of Test Pieces and Expression of Test; European Committee for Standardization: Brussels, Belgium, 1994.

25. EN 323. Wood-Based Panels. Determination of Density; European Committee for Standardization: Brussels, Belgium, 1993.

26. EN 309. Particleboards. Definitions and Classification; European Committee for Standardization: Brussels, Belgium, 2005.

27. EN 317. Particleboards and Fiberboards. Determination of Swelling in Thickness after Immersion in Water; European Committee for Standardization: Brussels, Belgium, 1993.

28. EN 319. Particleboards and Fiberboards. Determination of Tensile Strength Perpendicular to the Plane of the Board; European Committee for Standardization: Brussels, Belgium, 1993.

29. EN 310. Wood-Based Panels. Determination of Modulus of Elasticity in Bending and of Bending Strength; European Committee for Standardization: Brussels, Belgium, 1993.

30. EN 12667. Thermal Performance of Building Materials and Products: Determination of Thermal Resistance by Means of Guarded Hot Plate and Heat Flow Meter Methods: Products of High and Medium Thermal Resistance; European Committee for Standardization: Brussels, Belgium, 2001. 
31. García-Ortuño, T.; Andréu-Rodríguez, J.; Ferrández-García, M.T.; Ferrández-Villena, M.; Ferrández-García, C.E. Evaluation of the physical and mechanical properties of particleboard made from giant reed (Arundo donax L.). BioResources 2011, 6, 477-486.

32. EN 312. Particleboards_Specifications; European Committee for Standardization: Brussels, Belgium, 2010.

33. Nicolajsen, A. Thermal transmittance of a cellulose loose-fill insulation material. Build. Environ. 2005, 40, 907-914. [CrossRef]

34. Agoudjil, B.; Benchabane, A.; Boudenne, A.; Ibos, L.; Fois, M. Renewable materials to reduce building heat loss: Characterization of date palm wood. Energy Build. 2011, 43, 491-497. [CrossRef]

35. EN ISO 10456. Building Materials and Products. Hygrothermal Properties. Tabulated Design Values and Procedures for Determining Declared and Design Thermal Values; ISO: Geneva, Switzerland, 2007.

(C) 2019 by the authors. Licensee MDPI, Basel, Switzerland. This article is an open access article distributed under the terms and conditions of the Creative Commons Attribution (CC BY) license (http://creativecommons.org/licenses/by/4.0/). 